\title{
Antiparasitic activities of novel ruthenium/lapachol complexes
}

\author{
Marília I.F. Barbosa ${ }^{\text {a }}$, Rodrigo S. Corrêa ${ }^{\text {a }}$, Katia Mara de Oliveira ${ }^{\text {a }}$, Claudia Rodrigues ${ }^{\text {a }}$, Javier Ellena ${ }^{\text {b }}$, \\ Otaciro R. Nascimento ${ }^{\text {b }}$, Vinícius P.C. Rocha ${ }^{\mathrm{c}}$, Fabiana R. Nonato ${ }^{\mathrm{c}}$, Taís S. Macedo ${ }^{\mathrm{c}}$, José Maria Barbosa-Filho ${ }^{\mathrm{e}}$, \\ Milena B.P. Soares ${ }^{\mathrm{c}, \mathrm{d}}$, Alzir A. Batista ${ }^{\mathrm{a}, *}$ \\ a Departamento de Química, Universidade Federal de São Carlos, CP 676, CEP 13565-905, São Carlos (SP), Brazil \\ b Instituto de Física de São Carlos, Universidade de São Paulo, CP 369, CEP 13560-970, São Carlos (SP), Brazil \\ c Laboratório de Engenharia Tecidual e Imunofarmacologia, Fiocruz, CEP: 40296-710, Salvador (BA), Brazil \\ d Centro de Biotecnologia e Terapia Celular, Hospital São Rafael, CEP 41253-190, Salvador (BA), Brazil \\ e Universidade Federal da Paraíba Laboratório de Tecnologia Farmacêutica, CEP 58051-900, João Pessoa (PB), Brazil
}

\section{A R T I C L E I N F O}

\section{Article history:}

Received 29 November 2013

Received in revised form 19 March 2014

Accepted 19 March 2014

Available online 27 March 2014

\section{Keywords:}

Ruthenium (II) and (III) lapachol complex

Cytotoxicity

Antileishmanial and antiplasmodial activities

\begin{abstract}
A B S T R A C T
The present study describes the synthesis, characterization, antileishmanial and antiplasmodial activities of novel diimine/(2,2'-bipyridine (bipy), 1,10-phenanthroline (phen), 4,4'-methylbipyridine (Me-bipy) and 4,4'methoxybipyridine (MeO-bipy)/phosphine/ruthenium(II) complexes containing lapachol (Lap, 2-hydroxy-3(3-33 methyl-2-buthenyl)-1,4-naphthoquinone) as bidentate ligand. The $\left[\mathrm{Ru}(\mathrm{Lap})\left(\mathrm{PPh}_{3}\right)_{2}\right.$ (bipy)]PF $\mathrm{PF}_{6}$ (1), $\left[\mathrm{Ru}(\mathrm{Lap})\left(\mathrm{PPh}_{3}\right)_{2}(\mathrm{Me}-\right.$ bipy $\left.)\right] \mathrm{PF}_{6}(\mathbf{2}),\left[\mathrm{Ru}(\mathrm{Lap})\left(\mathrm{PPh}_{3}\right)_{2}(\mathrm{MeO}-\mathrm{bipy})\right] \mathrm{PF}_{6}$ (3) and $\left.\mathrm{Ru}(\mathrm{Lap})\left(\mathrm{PPh}_{3}\right)_{2}(\mathrm{phen})\right] \mathrm{PF}_{6}(\mathbf{4})$ complexes, $\mathrm{PPh}_{3}=$ triphenylphospine, were synthesized from the reactions of cis-[ $\left[\mathrm{RuCl}_{2}\left(\mathrm{PPh}_{3}\right)_{2}(\mathrm{X}\right.$-bipy) $]$ or cis-[ $\mathrm{RuCl}_{2}\left(\mathrm{PPh}_{3}\right)_{2}$ (phen)], with lapachol. The $\left[\mathrm{RuCl}_{2}(\mathrm{Lap})(\mathrm{dppb})\right]$ (5) [dppb $=1,4$-bis(diphenylphosphine)butane] was synthesized from the mer-[ $\left.\mathrm{RuCl}_{3}(\mathrm{dppb})\left(\mathrm{H}_{2} \mathrm{O}\right)\right]$ complex. The complexes were characterized by elemental analysis, molar conductivity, infrared and UV-vis spectroscopy, ${ }^{31} \mathrm{P}\left\{{ }^{1} \mathrm{H}\right\}$ and ${ }^{1} \mathrm{H} \mathrm{NMR}$, and cyclic voltammetry. The $\mathrm{Ru}(\mathrm{III})$ complex, $\left[\mathrm{RuCl}_{2}(\mathrm{Lap})(\mathrm{dppb})\right]$, was also characterized by the EPR technique. The structure of the complexes $\left[\mathrm{Ru}(\mathrm{Lap})\left(\mathrm{PPh}_{3}\right)_{2}\right.$ (bipy)] $\mathrm{PF}_{6}$ and $\left[\mathrm{RuCl}_{2}(\mathrm{Lap})(\mathrm{dppb})\right]$ was elucidated by X-ray diffraction. The evaluation of the antiparasitic activities of the complexes against Leishmania amazonensis and Plasmodium falciparum demonstrated that lapachol-ruthenium complexes are more potent than the free lapachol. The $\left[\mathrm{RuCl}_{2}(\mathrm{Lap})(\mathrm{dppb})\right] \mathrm{com}-$ plex is the most potent and selective antiparasitic compound among the five new ruthenium complexes studied in this work, exhibiting an activity comparable to the reference drugs.
\end{abstract}

(c) 2014 Elsevier Inc. All rigts reserved.

\section{Introduction}

Leishmaniasis and malaria are diseases caused by protozoan parasites and are characterized by high morbidity. It is estimated that leishmania disease causes about seventy thousand deaths annually and malaria kills around 1 million children only in Africa [1]. The first line treatment for leishmaniasis still relies on the use of pentavalent antimonials, although other drugs are also used for the treatment of Leishmania infection, such as pentamidine isethionate, amphotericin B and miltefosine [2,3]. Malaria treatment relies on the use of quinolinebased drugs, such as chloroquine, primaquine and mefloquine, as well as antifolates and artemisinin derivatives, depending on the parasite's susceptibility [4]. Common problems with these antiparasitic drugs are severe side effects and development of drug resistance. Based on this scenery, the research of new active compounds against these parasites is pivotal.

\footnotetext{
* Corresponding author. Tel.: + 55 1633518285; fax: + 551633518350 .

E-mail address: daab@power.ufscar.br (A.A. Batista).
}

The Tabebuia genus, belonging to the bignoniaceae plant family, is widely used in the traditional medicine in South America [5,6]. Among the active secondary metabolites present in this genus, 2-hydroxy-3(3-methyl-2-buthenyl)-1,4-naphthoquinone (lapachol, Fig. 1) is one of the most studied. Lapachol is endowed with anticancer and antimicrobial properties $[7,8]$. Because of its antiproliferative activity, lapachol has been employed as a prototype for the design and synthesis of new anticancer and antimicrobial agents. This has led to the identification of fewer lapachol derivatives with an enhanced activity [9-12].

Like other naphthoquinones [13,14], lapachol is a feasible ligand for the preparation of coordinating or organometallic compounds. In fact, there are some findings showing that lapachol-metal complexes are biologically more active than the free molecule [15-18]. Ruthenium complexes are considered to be one of the most promising types of metal compounds for cancer treating, due its interesting chemical properties, such as: versatility in ligand exchange, octahedral geometry and variability of oxidation states [19,20]. Recently it was observed that the lapachol-Ru(II) complex is a more potent anticancer agent than lapachol-Os(II) and Rh(III) complexes [18], suggesting that the use of ruthenium is promising to improve the biological activity of lapachol. 
<smiles>CC(C)=CCC1=C(O)C(=O)c2ccccc2C1=O</smiles>

Fig. 1. Lapachol structure.

Therefore, the present study describes the synthesis, characterization, antileishmanial and antiplasmodial activities of novel diimines $\left(2,2^{\prime}-\right.$ bipyridine (bipy), 1,10-phenantroline (phen), 4,4'-methylbipyridine (Me-bipy) and 4,4'-methoxybipyridine (MeO-bipy) and monophosphine ruthenium(II) and (III) complexes containing lapachol as a bidentate ligand.

\section{Experimental section}

\subsection{Materials for synthesis}

Solvents were purified by standard methods. All chemicals used were of reagent grade or comparable purity. The $\mathrm{RuCl}_{3} \cdot 3 \mathrm{H}_{2} \mathrm{O}$ was purchased from Degussa or Aldrich. The ligands 1,4-bis(diphenylphosphino)butane (dppb), triphenylphosphine (TPP), bipy, Me-bipy, MeO-bipy and phen were used as received from Aldrich.

\subsection{Instrumentation}

Elemental analyses were performed in a Fisons EA 1108 model (Thermo Scientific). The IR spectra of the powder complexes were recorded using CsI pellets in the $4000-200 \mathrm{~cm}^{-1}$ region in a BomenMichelson FT MB-102 instrument. The UV-Visible (UV-vis) spectra of the complex were recorded in $\mathrm{CH}_{2} \mathrm{Cl}_{2}$ solution, in a Hewlett Packard diode array-8452A. The electron paramagnetic resonance (EPR) spectrum was measured in solid state at $-160{ }^{\circ} \mathrm{C}$ using a Varian $\mathrm{E}-109$ instrument, recorded at the $\mathrm{X}$ band frequency, within a rectangular cavity (E-248) fitted with a temperature controller. Cyclic voltammetry (CV) experiments of the complexes in solution were promoted in an electrochemical analyzer BAS model 100B. These experiments were carried out at room temperature, in $\mathrm{CH}_{2} \mathrm{Cl}_{2}$ containing $0.10 \mathrm{M}$ $\mathrm{Bu}_{4} \mathrm{~N}^{+} \mathrm{ClO}_{4}^{-}$(TBAP) (FlukaPurum) as support electrolyte, and using an one-compartment cell, with both working and auxiliary electrodes, which were stationary $\mathrm{Pt}$ foils, while the reference electrode was $\mathrm{Ag} / \mathrm{AgCl}, 0.10 \mathrm{M}$ TBAP in $\mathrm{CH}_{2} \mathrm{Cl}_{2}$. Under these conditions, the ferrocene is oxidized at $0.43 \mathrm{~V}\left(\mathrm{Fc}^{+} / \mathrm{Fc}\right)$.

All NMR experiments were run on a BRUKER, DRX400 MHz equipment, in a BBO $5 \mathrm{~mm}$ probe, at $298 \mathrm{~K}$, and TMS (tetramethylsilane) for internal reference. For ${ }^{1} \mathrm{H}$ and ${ }^{13} \mathrm{C}$ NMR, DMSO- $d_{6}$ was used as solvent, while $\mathrm{CH}_{2} \mathrm{Cl}_{2}$ was used as solvent for $\left({ }^{31} \mathrm{P}\left\{{ }^{1} \mathrm{H}\right\}\right)$ NMR. The splitting of proton, carbon and phosphorus resonances was reported as $\mathrm{s}=$ singlet and $\mathrm{m}=$ multiplet.

\subsection{X-ray crystallography}

Blue single crystals of complexes (1) and (5) were grown by slow evaporation of a dichloromethane/ $n$-hexane solution. X-ray diffraction experiments were carried out using a suitable crystal mounted on glass fiber, and positioned on the goniometer head. Intensity data were measured with the crystal at room temperature on an EnrafNonius Kappa-CCD diffractometer with graphite monochromated MoK $\alpha$ radiation $(\lambda=0.71073 \AA)$. The cell refinements were performed using the software Collect [21] and Scalepack [22], and the final cell parameters were obtained on all reflections. Data reduction was carried out using the software Denzo-SMN and Scalepack [22]. The structures were solved by the Direct method using SHELXS-97 [15] and refined using the software SHELXL-97 [23]. A Gaussian method implemented was used for the absorption corrections [24]. Non-hydrogen atoms of the complexes were unambiguously located, and a full-matrix, leastsquare refinement of these atoms with anisotropic thermal parameters was carried out. The aromatic $\mathrm{C}-\mathrm{H}$ hydrogen atoms were positioned stereochemically and were refined with fixed individual displacement parameters $\left[\mathrm{U}_{\mathrm{iso}}(\mathrm{H})=1.2 \mathrm{U}_{\mathrm{eq}}\left(\mathrm{Csp}^{2}\right)\right]$ using a riding model with an aromatic, $\mathrm{C}-\mathrm{H}$ bond length fixed at $0.93 \mathrm{~A}$. Methylene groups of the dppb ligand in the complex (5), and methine group of the lapachol were set as isotropic with a thermal parameter $20 \%$ greater than the equivalent isotropic displacement parameter of the atom to which each one was bonded, whereas methyl groups were set with $U_{\text {iso }}(H)$ values of $1.5 \mathrm{U}_{\text {eq }}\left(\mathrm{C}_{\text {methyl }}\right)$. Tables were generated by WinGX [25] and the structure representations by ORTEP-3 [18] and MERCURY [21]. The main crystal data collections and structure refinement parameters for (1) and (5) are summarized in Table 1.

\subsection{Synthesis}

All the solvents used in this work were of reagent quality and used without further purification. Lapachol was obtained according to the procedure described in [24]. The precursors cis-[ $\left.\mathrm{RuCl}_{2}\left(\mathrm{PPh}_{3}\right)_{2}(\mathrm{X}-\mathrm{bipy})\right]$ $(\mathrm{X}=\mathrm{H}$, methyl $(\mathrm{Me})$ and methoxy $(\mathrm{MeO}))$ and cis- $\left[\mathrm{RuCl}_{2}\left(\mathrm{PPh}_{3}\right)_{2}\right.$ (phen)] were prepared according to literature [26,27]. Typically [100.0 mg; $0.1 \mathrm{mmol}]$ of the $\left[\mathrm{RuCl}_{2}\left(\mathrm{PPh}_{3}\right)_{3}\right]$ was dissolved in degassed $20 \mathrm{~mL}$ of dichloromethane (Merck) and N-heterocyclic (X-bipy or

Table 1

Crystal data and structure refinement for complex $\left[\mathrm{Ru}(\mathrm{Lap})\left(\mathrm{PPh}_{3}\right)_{2}(\right.$ bipy $\left.)\right] \mathrm{PF}_{6}(\mathbf{1})$ and $\left[\mathrm{RuCl}_{2}(\mathrm{Lap})(\mathrm{dppb})\right](5)$.

\begin{tabular}{|c|c|c|}
\hline & {$\left[\mathrm{Ru}(\right.$ Lap $)\left(\mathrm{PPh}_{3}\right)_{2}($ bipy $\left.)\right] \mathrm{PF}_{6}$} & {$\left[\mathrm{RuCl}_{2}(\mathrm{Lap})(\mathrm{dppb})\right]$} \\
\hline Empirical formula & {$\left[\mathrm{RuC}_{61} \mathrm{H}_{51} \mathrm{~N}_{2} \mathrm{O}_{3} \mathrm{P}_{2}\right] \mathrm{PF}_{6}$} & {$\left[\mathrm{RuC}_{43} \mathrm{H}_{41} \mathrm{Cl}_{2} \mathrm{O}_{3} \mathrm{P}_{2}\right]$} \\
\hline Formula weight & 1168.02 & 839.67 \\
\hline Crystal system & Monoclinic & Monoclinic \\
\hline Space group & $\mathrm{P} 2_{1} / \mathrm{c}$ & $\mathrm{P} 2_{1} / \mathrm{c}$ \\
\hline \multicolumn{3}{|l|}{ Unit cell dimensions } \\
\hline $\mathrm{a}(\AA)$ & $15.950(5)$ & $9.1790(1)$ \\
\hline $\mathrm{b}(\AA)$ & $16.744(5)$ & $29.6950(5)$ \\
\hline$c(\AA)$ & $20.316(5)$ & $14.7120(3)$ \\
\hline$\beta\left({ }^{\circ}\right)$ & $93.151(5)$ & $104.564(1)$ \\
\hline Volume $\left(\AA^{3}\right)$ & $5418(3)$ & $3881.20(11)$ \\
\hline Z & 4 & 4 \\
\hline $\begin{array}{l}\text { Density calculated } \\
\quad\left(\mathrm{Mg} / \mathrm{m}^{3}\right)\end{array}$ & 1.432 & 1.437 \\
\hline$\mu\left(\mathrm{mm}^{-1}\right)$ & 0.447 & 0.663 \\
\hline $\mathrm{F}(000)$ & 2392 & 1724 \\
\hline Crystal size $\left(\mathrm{mm}^{3}\right)$ & $0.26 \times 0.28 \times 0.53$ & $0.11 \times 0.19 \times 0.29$ \\
\hline$\theta$ range $\left({ }^{\circ}\right)$ & 2.96 to $26.76^{\circ}$ & 2.94 to $26.75^{\circ}$ \\
\hline \multirow[t]{3}{*}{ Index ranges } & $-20 \leq \mathrm{h} \leq 20$ & $-11 \leq \mathrm{h} \leq 8$ \\
\hline & $-19 \leq \mathrm{k} \leq 21$ & $-37 \leq \mathrm{k} \leq 37$ \\
\hline & $-25 \leq 1 \leq 23$ & $-18 \leq 1 \leq 18$ \\
\hline Reflections collected & 36,197 & 27,401 \\
\hline Independent reflections & $11,479[\mathrm{R}(\mathrm{int})=0.0423]$ & $8251[\mathrm{R}($ int $)=0.0617]$ \\
\hline Completeness to $\theta$ & $99.4 \%$ & $99.7 \%$ \\
\hline $\begin{array}{l}\text { Max. and min. } \\
\text { transmission }\end{array}$ & 0.942 and 0.795 & 0.947 and 0.867 \\
\hline $\begin{array}{c}\text { Data/restraints/ } \\
\text { parameters }\end{array}$ & $11,479 / 0 / 687$ & $8251 / 0 / 462$ \\
\hline Goodness-of-fit on $\mathrm{F}^{2}$ & 1.209 & 1.129 \\
\hline $\begin{array}{l}\text { Final } R \text { indices } \\
\qquad[\mathrm{I}>2 \operatorname{sigma}(\mathrm{I})]\end{array}$ & $\begin{array}{l}\mathrm{R} 1=0.0566 \\
\mathrm{wR} 2=0.1321\end{array}$ & $\begin{array}{l}\mathrm{R} 1=0.0376 \\
\mathrm{wR} 2=0.0724\end{array}$ \\
\hline $\mathrm{R}$ indices (all data) & $\begin{array}{l}\mathrm{R} 1=0.0669 \\
\mathrm{wR} 2=0.1386\end{array}$ & $\begin{array}{l}\mathrm{R} 1=0.0692, \\
\mathrm{wR} 2=0.0776\end{array}$ \\
\hline $\begin{array}{l}\Delta \rho_{\text {max }} \text { and } \Delta \rho_{\text {min }} . \\
\left(\mathrm{e} . \AA^{-3}\right)\end{array}$ & 0.553 and -0.641 & 0.557 and -0.541 \\
\hline
\end{tabular}


phen) [22.0 mg; $0.11 \mathrm{mmol}]$ ligand was added. The reaction mixture was stirred for $30 \mathrm{~min}$ at room temperature and the volume of the resulting blue solution was reduced, under vacuum, to ca. $2 \mathrm{~mL}$ and diethyl ether (Merck) was then added to precipitate a red solid, which was filtered off, washed several times with diethyl ether, and dried under vacuum. Yield: $78 \mathrm{mg}(80-90 \%)$.

Microanalyses suggested the formation of the complexes with general formula $\left[\mathrm{Ru}(\mathrm{Lap})\left(\mathrm{PPh}_{3}\right)_{2}\right.$ (bipy)]PF $6(\mathbf{1})$, $\left[\mathrm{Ru}(\mathrm{Lap})\left(\mathrm{PPh}_{3}\right)_{2}(\mathrm{Me}-\right.$ bipy)]PF 6 (2), [Ru(Lap) $\left(\mathrm{PPh}_{3}\right)_{2}(\mathrm{MeO}-$ bipy) $] \mathrm{PF}_{6}$ (3), [Ru(Lap) $\left(\mathrm{PPh}_{3}\right)_{2}$ (phen) $] \mathrm{PF}_{6}$ (4) and $\left[\mathrm{RuCl}_{2}\right.$ (Lap)(dppb)] (5). The molar conductivity data reveal that the complex $\mathbf{5}\left(3.46 \mu \mathrm{Sm}^{-1}\right)$ is non-electrolyte and complexes 1-4 (129.1, 146.8, 166.2 and $125.0 \mu \mathrm{sm}^{-1}$ respectively) are $1: 1$ electrolytes $\left(\mathrm{CH}_{2} \mathrm{Cl}_{2}\right)$, in accordance with the proposed formulations.

\subsection{1. [Ru(Lap) $\left(P P h_{3}\right)_{2}\left(X\right.$-bipy)] and [Ru(Lap) $\left(P P h_{3}\right)_{2}$ (phen)]}

The ruthenium(II) complexes with $\mathrm{N}-\mathrm{N}=$ bipy(1), Me-bipy(2), MeO-bipy(3) and phen(4) were prepared by reacting an excess of lapachol ligand $(0.137 \mathrm{mmol} ; 33.0 \mathrm{mg})$, previously dissolved in degassed mixture of $\mathrm{CH}_{2} \mathrm{Cl}_{2}$ :MeOH (50:50) solvent, and the same equivalent of triethylamine $\mathrm{Et}_{3} \mathrm{~N}$, and the cis- $\left[\mathrm{RuCl}_{2}\left(\mathrm{PPh}_{3}\right)_{2}(\mathrm{~N}-\mathrm{N})\right]$ precursors $(0.114 \mathrm{mmol} ; \cong 100.0 \mathrm{mg})$. The reaction mixture was refluxed and stirred for about $72 \mathrm{~h}$, under Ar atmosphere. The final blue solutions were concentrated to ca. $2 \mathrm{~mL}$ and $10 \mathrm{~mL}$ of water was added in order to obtain dark blue precipitates. The solids were filtered off, well rinsed with water and diethyl ether and dried in vacuum.

2.4.1.1. $\left[R u(L a p)\left(P P h_{3}\right)_{2}\right.$ (bipy) $] P F_{6}$ (1). Yield: $121 \mathrm{mg}$ (88\%). Anal. calcd for $\mathrm{C}_{61} \mathrm{H}_{51} \mathrm{~F}_{6} \mathrm{~N}_{2} \mathrm{O}_{3} \mathrm{P}_{3} \mathrm{Ru}$ : exptl (calc) C, 62.30 (62.72); $\mathrm{H}, 4.20$ (4.40); N, 2.18 (2.40). ${ }^{31} \mathrm{P}\left\{{ }^{1} \mathrm{H}\right\}$ NMR: $\delta(\mathrm{ppm}) 29.3(\mathrm{~s}) ;{ }^{1} \mathrm{H}$ NMR $(400.21 \mathrm{MHz}$, DMSO- $\left.d_{6}, 298 \mathrm{~K}\right): \delta(\mathrm{ppm}) 9.80-7.00$ (overlapped signals, $30 \mathrm{H}$ aromatic hydrogen for $\mathrm{PPh}_{3}$ and $14 \mathrm{H}$ aromatic hydrogen for bipy and Lap) 4.88 (m, $1 \mathrm{H}, \mathrm{CH}$ of Lap); 3.22 (m, 2H, CH $\mathrm{CH}_{2}$ Lap); 1.83 (s, 3H, $\mathrm{CH}_{3}$ of Lap); 1.56 (s, 3H, $\mathrm{CH}_{3}$ of Lap). ${ }^{13} \mathrm{C}$ NMR $\left(400.21 \mathrm{MHz}\right.$, DMSO- $\left.d_{6}, 298 \mathrm{~K}\right)$ : $\delta(\mathrm{ppm}) 198.1\left(\mathrm{C}_{1}=\mathrm{O}\right.$ of Lap), $180.6\left(\mathrm{C}_{4}=\mathrm{O}\right.$ of Lap), $167.2\left(\mathrm{C}_{2}-\mathrm{O}\right.$ of Lap). UV-vis $\left(\mathrm{CH}_{2} \mathrm{Cl}_{2}, 10^{-5} \mathrm{M}\right): \lambda / \mathrm{nm}\left(\varepsilon / \mathrm{M}^{-1} \mathrm{~L} \mathrm{~cm}^{-1}\right) 370$ (shoulder), $573\left(6.30 \times 10^{3}\right)$.

2.4.1.2. [Ru(Lap) $\left(\mathrm{PPh}_{3}\right)_{2}\left(\mathrm{Me}\right.$-bipy)]PF $\mathrm{P}_{6} \mathrm{CH}_{3} \mathrm{OH}$ (2). Yield: $115 \mathrm{mg}$ (84\%). Anal. calc. for $\mathrm{C}_{64} \mathrm{H}_{59} \mathrm{~F}_{6} \mathrm{~N}_{2} \mathrm{O}_{4} \mathrm{P}_{3} \mathrm{Ru}$ : $\exp$ (calc) C, 62.70 (62.59); H, 4.61 (4.84); N, 2.32 (2.28). ${ }^{31} \mathrm{P}\left\{{ }^{1} \mathrm{H}\right\}$ NMR: $\delta(\mathrm{ppm}) 29.1(\mathrm{~s}) ;{ }^{1} \mathrm{H}$ NMR (400.21 MHz, DMSO- $\left.d_{6}, 298 \mathrm{~K}\right): \delta(\mathrm{ppm}) 2.30\left(\mathrm{~s}, 3 \mathrm{H}, \mathrm{CH}_{3}\right) ; 2.42(\mathrm{~s}, 3 \mathrm{H}$, $\mathrm{CH}_{3}{ }^{\prime}$ ) (aliphatic hydrogen for Me-bipy); 8.09-7.00 (overlapped signals, $30 \mathrm{H}$ aromatic hydrogen for $\mathrm{PPh}_{3}$ and $8 \mathrm{H}$ aromatic hydrogen of Mebipy); 4.87 (m, 1H, CH of Lap); 3.19 (m, 2H, $\mathrm{CH}_{2}$ of Lap); 1.81 (s, 3H, $\mathrm{CH}_{3}$ of Lap); 1.55 (s, $\mathrm{CH}_{3}$ of Lap). ${ }^{13} \mathrm{C}$ NMR (400.21 MHz, DMSO- $d_{6}$, $298 \mathrm{~K}): \delta(\mathrm{ppm}) 198.7\left(\mathrm{C}_{1}=\mathrm{O}\right.$ of Lap), 182.3 ( $\mathrm{C}_{4}=\mathrm{O}$ of Lap), 168.0 ( $\mathrm{C}_{2}-\mathrm{O}$ of Lap). UV-vis $\left(\mathrm{CH}_{2} \mathrm{Cl}_{2}, 10^{-5} \mathrm{M}\right): \lambda / \mathrm{nm}\left(\varepsilon / \mathrm{M}^{-1} \mathrm{~cm}^{-1}\right) 297$ (shoulder), $572\left(6.40 \times 10^{3}\right)$.

2.4.1.3. [Ru(Lap) $\left(\mathrm{PPh}_{3}\right)_{2}(\mathrm{MeO}$-bipy)]PF 6 (3). Yield: $110 \mathrm{mg}$ (84\%). Anal. calcd for $\mathrm{C}_{63} \mathrm{H}_{55} \mathrm{~F}_{6} \mathrm{~N}_{2} \mathrm{O}_{5} \mathrm{P}_{3} \mathrm{Ru}$ : exp.(calc) C, 61.97 (61.61); H, 4.39 (4.51); N, 2.43 (2.28). ${ }^{31} \mathrm{P}\left\{{ }^{1} \mathrm{H}\right\}$ NMR: $\delta(\mathrm{ppm}) 29.8(\mathrm{~s}) .{ }^{1} \mathrm{H}$ NMR $\left(400.21 \mathrm{MHz}, \mathrm{DMSO}-\mathrm{d}_{6}, 298 \mathrm{~K}\right): \delta(\mathrm{ppm}) 3.91\left(\mathrm{~s}, 3 \mathrm{H}, \mathrm{CH}_{3}\right) ; 3.84(\mathrm{~s}, 3 \mathrm{H}$, $\mathrm{CH}_{3}{ }^{\prime}$ ) (aliphatic hydrogen of MeO-bipy); 9.45-7.00 (overlapped signals, $30 \mathrm{H}$ aromatic hydrogen for $\mathrm{PPh}_{3}$ and $12 \mathrm{H}$ aromatic hydrogen for MeObipy and Lap); 4.85 (m, 1H, CH of Lap); 3.16 (m, 2H, $\mathrm{CH}_{2}$ of Lap); 1.80 (s, 3H, $\mathrm{CH}_{3}$ of Lap); 1.54 (s, $\mathrm{CH}_{3}$ of Lap). ${ }^{13} \mathrm{C}$ NMR (400.21 MHz, DMSO$\left.d_{6}, 298 \mathrm{~K}\right): \delta(\mathrm{ppm}) 198.2\left(\mathrm{C}_{1}=\mathrm{O}\right.$ of Lap), $180.4\left(\mathrm{C}_{4}=\mathrm{O}\right.$ of Lap), 167.6 $\left(\mathrm{C}_{2}-\mathrm{O}\right.$ of Lap). UV-vis $\left(\mathrm{CH}_{2} \mathrm{Cl}_{2}, 10^{-5} \mathrm{M}\right): \lambda / \mathrm{nm}\left(\varepsilon / \mathrm{M}^{-1} \mathrm{~cm}^{-1}\right) 297$ (shoulder), $586\left(6.11 \times 10^{3}\right)$.

2.4.1.4. [Ru(Lap) $\left(\mathrm{PPh}_{3}\right)_{2}$ (phen)]PF 6 (4). Yield: $128 \mathrm{mg}$ (94\%). Anal. calcd for $\mathrm{C}_{63} \mathrm{H}_{51} \mathrm{~F}_{6} \mathrm{~N}_{2} \mathrm{O}_{3} \mathrm{P}_{3} \mathrm{Ru}$ : exp.(calc) C, 63.97 (63.48); $\mathrm{H}, 3.99$ (4.31); N, 2.39 (2.35). ${ }^{31} \mathrm{P}\left\{{ }^{1} \mathrm{H}\right\}$ NMR: $\delta(\mathrm{ppm}) 32.6(\mathrm{~s}) .{ }^{1} \mathrm{H}$ NMR $(400.21 \mathrm{MHz}$, DMSO- $\left.d_{6}, 298 \mathrm{~K}\right): \delta(\mathrm{ppm}) 10.00-7.00$ (overlapped signals, $30 \mathrm{H}$ aromatic hydrogen of $\mathrm{PPh}_{3}$ and $18 \mathrm{H}$ aromatic hydrogen for phen and Lap); 4.91 (m, $1 \mathrm{H}, \mathrm{CH}$ of Lap); 3.26 ( $\mathrm{m}, 2 \mathrm{H}, \mathrm{CH}_{2}$ of Lap); 1.83 (s, 3H, $\mathrm{CH}_{3}$ of Lap); 1.55 (s, $\mathrm{CH}_{3}$ of Lap). ${ }^{13} \mathrm{CNMR}\left(400.21 \mathrm{MHz}\right.$, DMSO-d $\left.d_{6}, 298 \mathrm{~K}\right): \delta(\mathrm{ppm})$ 198.4 ( $C_{1}=0$ of Lap), 180.6 ( $C_{4}=0$ of Lap), 167.4 ( $C_{2}-O$ of Lap). UVvis $\left(\mathrm{CH}_{2} \mathrm{Cl}_{2}, 10^{-5} \mathrm{M}\right): \lambda / \mathrm{nm}\left(\varepsilon / \mathrm{M}^{-1} \mathrm{~L} \mathrm{~cm}^{-1}\right) 290$ (shoulder), 300 $\left(2.66 \times 10^{4}\right), 408\left(5.25 \times 10^{3}\right)$.

2.4.1.5. $\left[\mathrm{RuCl}_{2}(\mathrm{Lap})(\mathrm{dppb})\right]$, (5). The ruthenium (III) complex $\left[\mathrm{RuCl}_{2}\right.$ (Lap)(dppb)] (5) was prepared dissolving $(0.137 \mathrm{mmol} ; 33.0 \mathrm{mg})$ of lapachol ligand in a mixture of $\mathrm{CH}_{2} \mathrm{Cl}_{2}: \mathrm{MeOH}$ (50:50) solvent and the same equivalent of triethylamine $\left(\mathrm{Et}_{3} \mathrm{~N}\right)$ and then added the mer$\left[\mathrm{RuCl}_{3}(\mathrm{dppb})\left(\mathrm{H}_{2} \mathrm{O}\right)\right]$ [28] precursor $(0.137 \mathrm{mmol} ; 33.0 \mathrm{mg})$. The reaction mixture was refluxed and stirred for $24 \mathrm{~h}$, under $\mathrm{Ar}$ atmosphere. The final purple solution was concentrated to ca. $2 \mathrm{~mL}$, and $10 \mathrm{~mL}$ of diethyl ether was added in order to obtain dark purple precipitate. The solid was filtered off, well rinsed with diethyl ether and dried in vacuo. Yield: $189 \mathrm{mg}$ (98\%). Anal. calc. for $\mathrm{C}_{43} \mathrm{H}_{41} \mathrm{Cl}_{2} \mathrm{O}_{3} \mathrm{P}_{2} \mathrm{Ru}$ : exp. (calc) C, 61.40 (61.50); H, 4.80 (4.92). UV-vis $\left(\mathrm{CH}_{2} \mathrm{Cl}_{2}, 10^{-5} \mathrm{M}\right): \lambda / \mathrm{nm}$ $\left(\varepsilon / \mathrm{M}^{-1} \mathrm{~L} \mathrm{~cm}^{-1}\right) 315$ (shoulder), 330 (shoulder), $356\left(2.77 \times 10^{3}\right)$ and $558\left(5.6 \times 10^{3}\right)$.

\subsection{Biological experiments}

\subsubsection{Cells and cultures}

Antiparasitic activity was performed with Leishmania amazonensis (MHOM/BR88/BA-125) and W2 strain Plasmodium falciparum, while hemolysis assays were done using $\mathrm{O}^{+}$human erythrocytes and cytotoxicity assays were done in $\mathrm{J} 774$ macrophages. The L. amazonensis promastigotes were maintained in Schneider's insect medium (SigmaAldrich, St. Louis, USA) supplemented with $10 \%$ fetal bovine serum (Gibco Laboratories, Gaithersburg, USA) and $50 \mu \mathrm{g} / \mathrm{mL}$ of gentamicin (Hipolabor, Belo Horizonte, Brazil). J774 macrophages were cultivated in RPMI-1640 medium (Sigma-Aldrich, St. Louis, USA) supplemented with $10 \%$ fetal bovine serum and $50 \mu \mathrm{g} / \mathrm{mL}$ of gentamicin. W2 strain $P$. falciparum was maintained in continuous culture of human erythrocytes (blood group $\mathrm{O}^{+}$) using RPMI-1640 medium supplemented with $10 \%$ human plasma without hypoxanthine.

\subsubsection{Cytotoxicity assays}

J774 macrophages $\left(5 \times 10^{4}\right.$ cells $\left./ \mathrm{mL}\right)$ were distributed in 96-well plate $(100 \mu \mathrm{L} /$ well $)$ and incubated for $24 \mathrm{~h}$ at $37{ }^{\circ} \mathrm{C}$ in $5 \% \mathrm{CO}_{2}$. Each drug was solubilized in DMSO as a stock solution and diluted in culture media in the tested concentrations ranging from 0.1 to $10 \mu \mathrm{g} / \mathrm{mL}$ (100 $\mu \mathrm{L} /$ well). The final concentration of DMSO was $0.1 \%$. Each concentration was tested in triplicate. After incubation for $72 \mathrm{~h}, 20 \mu \mathrm{L}$ of Alamar blue (Invitrogen, CA, USA) was added to each well and incubated for 24 $\mathrm{h}$ in the dark. Gentian violet was used as control. The absorbance was evaluated at 570 and $600 \mathrm{~nm}$ according to manufacturer's instructions. The $\mathrm{LC}_{50}$ values were calculated using a non-linear regression curve fit in the Prism version 5.03 (GraphPad Software).

For the hemolysis assay, human erythrocytes type $\mathrm{O}^{+}$were washed three times in phosphate buffered saline and $100 \mu \mathrm{L}$ of this suspension ( $1 \%$ hematocrit) was distributed into a 96 -well plate. Then, $100 \mu \mathrm{L}$ of each drug, previously dissolved in phosphate buffered saline, was added in triplicate to the plate and incubated for $1 \mathrm{~h}$. Saponin (SigmaAldrich, St. Louis, USA) was used as reference drug at $1 \% v / v$. After incubation the cells were centrifuged ( $1500 \mathrm{rpm}$ for $10 \mathrm{~min}$ ) and $100 \mu \mathrm{L}$ of each supernatant was transferred to another microtiter plate. Released haemoglobin was monitored by measuring the absorbance at $540 \mathrm{~nm}$ in a spectrophotometer. The percentage of hemolysis was determined in comparison to untreated cells.

\subsubsection{Antileishmanial activity against promastigotes}

L. amazonensis promastigotes $\left(2 \times 10^{6}\right.$ cells $\left./ \mathrm{mL}\right)$ in stationary growth phase were distributed in a 96 -well plate $(100 \mu \mathrm{L} /$ well $)$ at $24{ }^{\circ} \mathrm{C}$. Each drug was solubilized in DMSO as described above, 

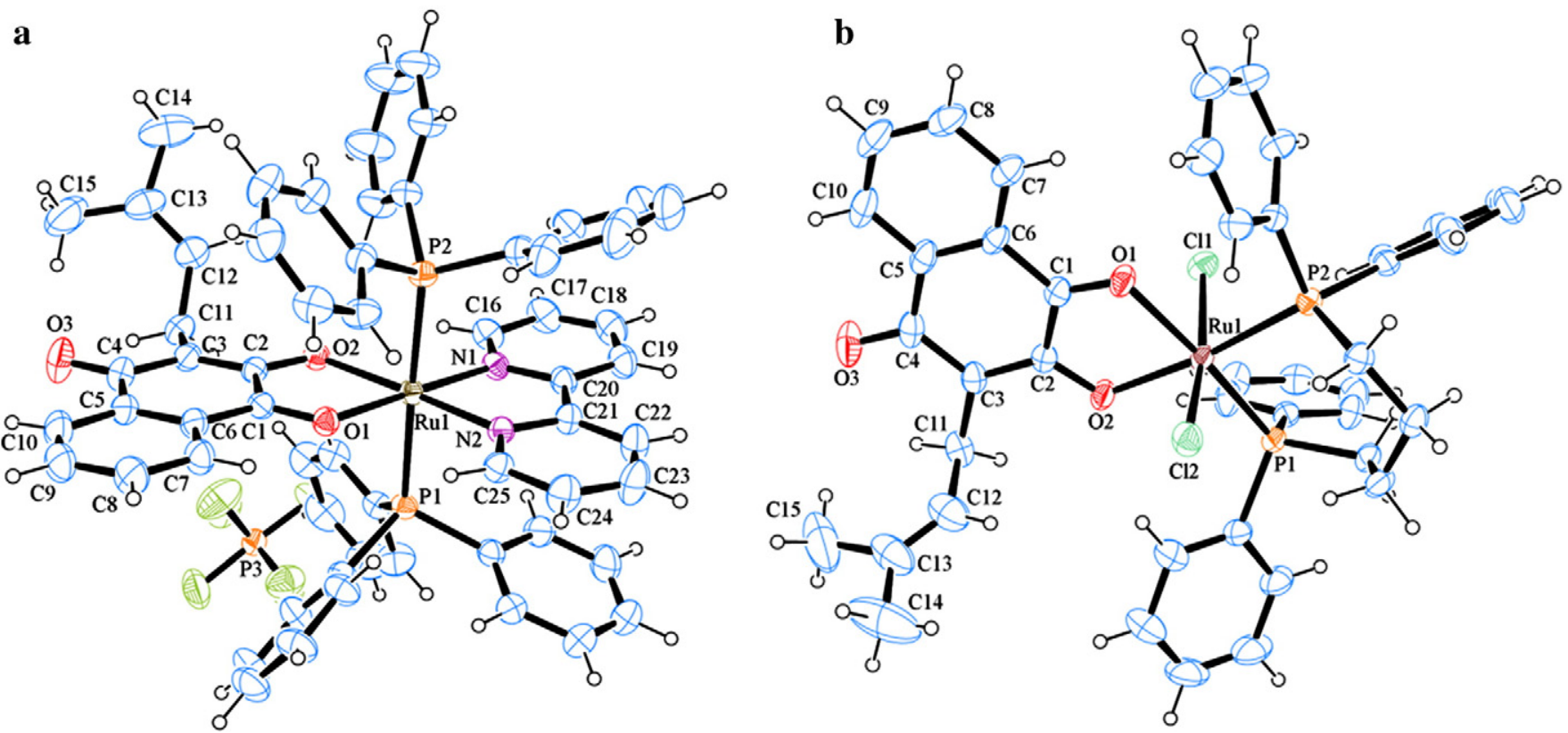

Fig. 2. X-ray structures for (a) $\left[\mathrm{Ru}(\mathrm{Lap})\left(\mathrm{PPh}_{3}\right)_{2}\right.$ (bipy) $] \mathrm{PF}_{6}(1)$ and (b) $\left[\mathrm{RuCl}_{2}(\mathrm{Lap})(\mathrm{dppb})\right](5)$, showing atoms labeling and $50 \%$ of probability ellipsoids.

diluted in the culture medium and added in serial dilution from 0.1 to $10 \mu \mathrm{g} / \mathrm{mL}$ (100 $\mu \mathrm{L} /$ well $)$. The final DMSO concentration was $0.1 \%$. Amphotericin B (Gibco Laboratories, Gaithersburg, USA) was used as reference drug. After $72 \mathrm{~h}$ incubation at $24{ }^{\circ} \mathrm{C}$, the number of viable parasites was counted in a Neubauer chamber. The $\mathrm{IC}_{50}$ values were calculated in Prism version 5.03 (GraphPad Software) using non-linear regression.

\subsubsection{In vitro leishmania infection}

J774 macrophages $\left(2 \times 10^{5}\right.$ cells $\left./ \mathrm{mL}\right)$ were plated in 96 -well plate $(100 \mu \mathrm{L} /$ well $)$ and incubated overnight at $37{ }^{\circ} \mathrm{C}$ in $5 \% \mathrm{CO}_{2}$. L. amazonensis promastigotes in the stationary growth phase were added to the cell culture ( $100 \mu \mathrm{L} /$ well) at a parasite/macrophage ratio of $10: 1$ and incubated for $24 \mathrm{~h}$. Plates were washed to remove nonphagocytosed parasites. Each drug, solubilized as described above, was added and incubated for $72 \mathrm{~h}$. Amphotericin B was used as reference drug. Infected macrophages were lysed by addition of $0.01 \%$ sodium dodecyl sulfate (Sigma-Aldrich, St. Louis, USA) in PBS (phosphate-buffered saline) at $37^{\circ} \mathrm{C}$ for $30 \mathrm{~min}$.

Amastigotes from lysed macrophages were incubated at $24{ }^{\circ} \mathrm{C}$ for $48 \mathrm{~h}$, which then differentiated in promastigotes. The number of viable

Table 2

Selected bond length $(\AA)$ and angles $\left({ }^{\circ}\right)$ for complexes $(\mathbf{1})$ and $(\mathbf{5})$.

\begin{tabular}{lll}
\hline Fragment & Complex (1) & Complex (5) \\
\hline $\mathrm{Ru}(1)-\mathrm{O}(1)$ & $2.0710(19)$ & $2.1707(15)$ \\
$\mathrm{Ru}(1)-\mathrm{O}(2)$ & $2.133(2)$ & $2.0580(15)$ \\
$\mathrm{Ru}(1)-\mathrm{P}(2)$ & $2.3952(11)$ & $2.3728(6)$ \\
$\mathrm{Ru}(1)-\mathrm{P}(1)$ & $2.4104(10)$ & $2.2910(6)$ \\
$\mathrm{Ru}(1)-\mathrm{N}(2)$ & $2.038(2)$ & - \\
$\mathrm{Ru}(1)-\mathrm{N} 1(1)$ & $2.050(2)$ & - \\
$\mathrm{Ru}(1)-\mathrm{Cl}(1)$ & - & $2.3308(7)$ \\
$\mathrm{Ru}(1)-\mathrm{Cl}(2)$ & - & $2.3343(7)$ \\
$\mathrm{O}(1)-\mathrm{C}(1)$ & $1.250(3)$ & $1.235(3)$ \\
$\mathrm{O}(2)-\mathrm{C}(2)$ & $1.308(3)$ & $1.309(3)$ \\
$\mathrm{O}(3)-\mathrm{C}(4)$ & $1.236(4)$ & $1.230(3)$ \\
$\mathrm{O}(2)-\mathrm{Ru}(1)-\mathrm{O}(1)$ & $76.22(7)$ & $77.85(6)$ \\
$\mathrm{O}(1)-\mathrm{Ru}(1)-\mathrm{P}(1)$ & $174.56(5)$ & $91.69(6)$ \\
$\mathrm{O}(2)-\mathrm{Ru}(1)-\mathrm{P}(2)$ & $90.02(6)$ & $171.11(5)$ \\
$\mathrm{O}(1)-\mathrm{Ru}(1)-\mathrm{P}(2)$ & $89.95(6)$ & $93.39(5)$ \\
$\mathrm{P}(1)-\mathrm{Ru}(1)-\mathrm{P}(2)$ & $178.25(3)$ & $92.01(2)$ \\
$\mathrm{Cl}(1)-\mathrm{Ru}(1)-\mathrm{Cl}(2)$ & - & $168.99(3)$ \\
\hline
\end{tabular}

promastigotes was determined by adding Alamar Blue ( $20 \mu \mathrm{L} /$ well $)$ and incubated for $24 \mathrm{~h}$. The absorbance was evaluated at 570 and $600 \mathrm{~nm}$ according to the manufacturer's instructions. The $\mathrm{IC}_{50}$ values were calculated in Prism version 5.03 (GraphPad Software) using non-linear regression.

\subsubsection{Antimalarial activity}

The antimalarial effects of the compounds were measured with the $\left[{ }^{3} \mathrm{H}\right]$-hypoxanthine (PerkinElmer, Boston, USA) incorporation assay. W2 P. falciparum grown at 1-2\% parasitemia and $2.5 \%$ hematocrit were aliquoted in a 96-well plate. Drugs were solubilized as described above in a concentration range of 0.1 to $10 \mu \mathrm{g} / \mathrm{mL}$; each concentration was performed in triplicates. Mefloquine (Farmanguinhos, Rio de Janeiro, RJ, Brazil) was used as reference drug. After $24 \mathrm{~h}$ of incubation with the tested compounds, $25 \mu \mathrm{L}$ of medium containing $\left[{ }^{3} \mathrm{H}\right.$ ]hypoxanthine $(0.5 \mu \mathrm{Ci} /$ well) was added per well, followed by another $24 \mathrm{~h}$ of incubation. The parasites were harvested using a cell harvester to evaluate the $\left[{ }^{3} \mathrm{H}\right]-$ hypoxanthine incorporation in a $\beta$-radiation counter (Multilabel Reader; Hidex, Turku, Finland). Inhibition of parasite growth was evaluated by comparing the $\left[{ }^{3} \mathrm{H}\right]$-hypoxanthine uptake in untreated versus treated cells. $\mathrm{IC}_{50}$ values were calculated in a Graph Pad Prism version 5.03 (Graph Pad Software, San Diego, CA) using non-linear regression.

\section{Results and discussion}

In this work the lapachol acted as bidentate ligand and monoanionic species, coordinating with the ruthenium atoms through its ortho oxygens $\left(01,02-\right.$ Fig. 1). The structures of the complexes $\left[\mathrm{Ru}(\mathrm{Lap})\left(\mathrm{PPh}_{3}\right)_{2}\right.$ (bipy) $] \mathrm{PF}_{6}$ (1) and $\left[\mathrm{RuCl}_{2}(\mathrm{Lap})(\mathrm{dppb})\right]$ (5) were confirmed based on X-ray diffraction data (see Fig. 2). These compounds crystallize in the

Table 3

Cyclic voltammetry data for complexes (1)-(4) (TBAP $0.1 \mathrm{M} ; \mathrm{CH}_{2} \mathrm{Cl}_{2} ; \mathrm{Ag} / \mathrm{AgCl}$; work electrode Pt; $100 \mathrm{mVs}^{-1}$ ).

\begin{tabular}{llll}
\hline Complex & $\mathrm{E}_{\mathrm{pa}}(\mathrm{V})$ & $\mathrm{E}_{1 / 2}(\mathrm{~V})$ & $\mathrm{pKa}(\mathrm{N}-\mathrm{N})$ \\
\hline$\left[\mathrm{Ru}(\mathrm{Lap})\left(\mathrm{PPh}_{3}\right)_{2}(\mathrm{bipy})\right] \mathrm{PF}_{6}(\mathbf{1})$ & 1.03 & 0.99 & 4.86 \\
{$\left[\mathrm{Ru}(\mathrm{Lap})\left(\mathrm{PPh}_{3}\right)_{2}(\mathrm{Me}-\mathrm{bipy})\right] \mathrm{PF}_{6}(\mathbf{2})$} & 0.96 & 0.87 & 4.92 \\
{$\left[\mathrm{Ru}(\mathrm{Lap})\left(\mathrm{PPh}_{3}\right)_{2}\left(\mathrm{MeO}-\mathrm{bipy}_{1}\right)\right] \mathrm{PF}_{6}(\mathbf{3})$} & 0.77 & 0.71 & 5.74 \\
{$\left[\mathrm{Ru}(\right.$ Lap $\left.)\left(\mathrm{PPh}_{3}\right)_{2}(\mathrm{phen})\right] \mathrm{PF}_{6}(\mathbf{4})$} & 1.08 & 1.00 & 4.44 \\
\hline
\end{tabular}




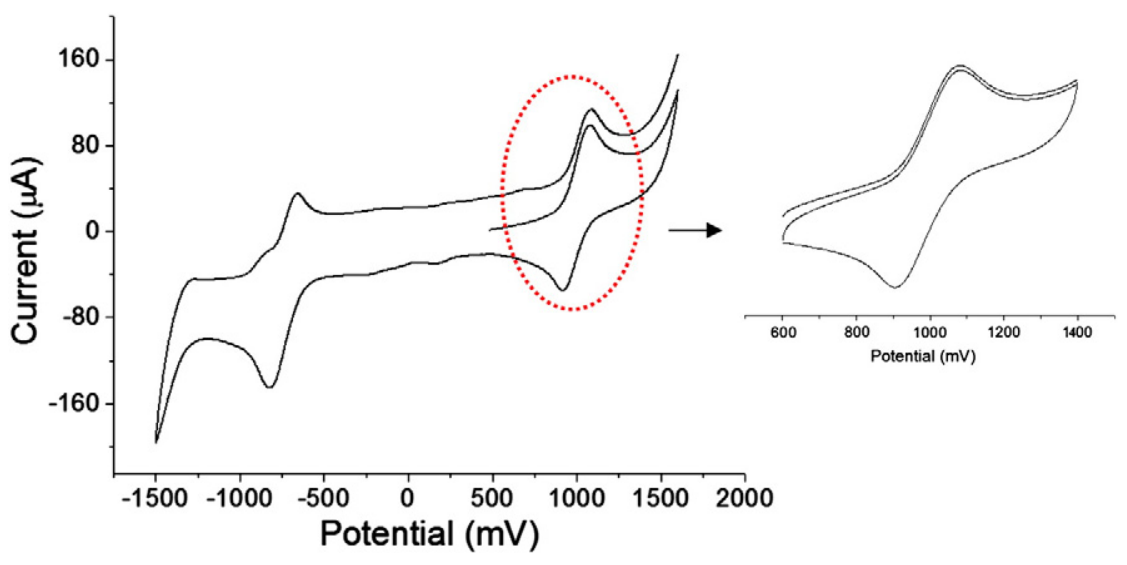

Fig. 3. Cyclic voltammogram of $\left[\mathrm{Ru}(\mathrm{Lap})\left(\mathrm{PPh}_{3}\right)_{2}\right.$ (phen) $] \mathrm{PF}_{6}$ (4) (TBAP $0.1 \mathrm{M} ; \mathrm{CH}_{2} \mathrm{Cl}_{2} ; \mathrm{Ag} / \mathrm{AgCl}$; work electrode Pt; $100 \mathrm{mV} \cdot \mathrm{s}^{-1}$ ).

monoclinic system, with the space group $\mathrm{P} 2 / \mathrm{c}$. It is observed that the $\mathrm{O} 1$ and $\mathrm{O} 2$ atoms are involved in the coordination, where $\mathrm{O} 2$, is negatively charged and 01, is neutral. A distorted octahedral geometry is observed for both crystal structures, as observed by the bond angles (Table 2).

Some distance and selected angles in the X-ray structure of complex (1) and (5) are shown in Table 2, which are, in general, in accordance with values expected for similar phosphine complexes of $\mathrm{Ru}(\mathrm{II})$ and $\mathrm{Ru}(\mathrm{III})$ for $\mathrm{Ru}-\mathrm{N}, \mathrm{Ru}-\mathrm{P}$ and $\mathrm{Ru}-\mathrm{Cl}$ [28-30]. But, it is interesting to point out that the distances of $\mathrm{Ru}(\mathrm{II})-\mathrm{O}$ for complex (1) are also in accordance with the expected values, where the distance Ru-02 [2.133(2) Ả] is longer than the distance Ru-01 [2.0710(19) Ả], since the 02 has charge minus one and its radius is bigger than the one for the neutral species. Therefore, the same was not observed for complex (5), where the distance $\mathrm{Ru}-\mathrm{O} 1$ [2.1707(15) Ả] is longer than the distance $\mathrm{Ru}-\mathrm{O} 2$ [2.0580(15) A]. Probably in this case the strong trans effect of phosphorus atoms is more effective when it is trans to neutral atoms, and not when it is trans to negatively charged atoms. As it can be seen in Table 2 the distance of $\mathrm{Ru}(\mathrm{III})-01$ is $0.1 \mathrm{~A}$ longer than $\mathrm{Ru}(\mathrm{II})-01$, showing the strong trans effect phosphorus atoms. On other hand the distance $\mathrm{Ru}(\mathrm{III})-\mathrm{O} 1$, is shorter than $\mathrm{Ru}(\mathrm{II})-\mathrm{O} 1$, as expected, considering the size of the radius of $\mathrm{Ru}(\mathrm{III})$ and $\mathrm{Ru}(\mathrm{II})$.

In the ${ }^{31} \mathrm{P}\left\{{ }^{1} \mathrm{H}\right\}$ NMR spectra of the complexes (1-4) just one singlet at about $30 \mathrm{ppm}$ is observed in all cases, indicating the magnetic equivalence of the two trans phosphorus atoms, as expected. Also, each ${ }^{31} \mathrm{P}$ $\left\{{ }^{1} \mathrm{H}\right\}$ NMR spectra exhibit a heptet signal at $-144 \mathrm{ppm}$, corresponding to the phosphorus atoms of the $\mathrm{PF}_{6}^{-}$counter ion. The EPR spectra in solid state, for complex (5), confirms the presence of Ru (III) paramagnetic species, showing $g_{1}=2.578, g_{2} 2.128$ and $g_{3}=1.822$ typical of ruthenium (III) complexes [29].

Cyclic voltammograms of Ru(II) complexes (1-4) show a quasireversible process between 0.71 and $1.0 \mathrm{~V}$, which correspond to the redox pair $\mathrm{Ru}(\mathrm{III}) / \mathrm{Ru}(\mathrm{II})$, as can be seen from the Table 3, and Fig. 3 for the case of complex (4). In the negative region a quasi-reversible oneelectron reduction process was observed in all cases, which most probably correspond to the ligand reduction to the semiquinone form [31]. As can be seen in Table 3 the redox potential of 1-4 decreases when the diimine basicity is increased. Analyzing the complex $\left[\mathrm{RuCl}_{2}\right.$ (Lap)(dppb)] (5), in the same experimental conditions, it is observed a $\mathrm{Ru}(\mathrm{III}) / \mathrm{Ru}(\mathrm{II})$ reversible process with $\mathrm{E} 1 / 2$ of $0.18 \mathrm{~V}$.

The IR spectra of complexes (1-5) confirm the presence of the lapachol ligand coordinated to the metal. The band located at $3351 \mathrm{~cm}^{-1}$ in the free lapachol [31,32] assigned to $\mathrm{OH}$, disappears upon coordination, as expected. The characteristic $\nu(C=0)$ stretching bands, found at $\nu\left(C_{1}=0\right) 1664$ and $\nu\left(C_{4}=0\right) 1641 \mathrm{~cm}^{-1}$ in free lapachol [11] shifted to lower frequencies in complexes, 1561-1591 $\mathrm{cm}^{-1}$ and 1581-1533 $\mathrm{cm}^{-1}$, respectively. This behavior was also observed for other complexes like $\mathrm{Ru}(\mathrm{II}), \mathrm{Co}(\mathrm{II}), \mathrm{Ni}(\mathrm{II})$ and $\mathrm{Cu}(\mathrm{II})$ containing the lapachol as ligand $[5,11,12]$. The characteristic $\nu\left(C_{2}-O\right)$ stretching band found in $1028 \mathrm{~cm}^{-1}$ in the free lapachol shifted to higher frequencies in complexes (1065-1079 $\mathrm{cm}^{-1}$ ). Finally, new bands of medium intensities, located below $500 \mathrm{~cm}^{-1}$ are present in the spectra of complexes, which may be related to metal-ligand vibrations.

The antiparasitic and toxicity of host cell were evaluated. For comparison, the metal-free lapachol was included in the pharmacological evaluation. Firstly, compounds were evaluated on their ability to inhibit the $L$. amazonensis promastigote proliferation, as well as against intracellular amastigotes, according to standard methodology [33]. Secondly, the antimalarial activity of the complexes was determined against the erythrocytic stage of W2 strain $P$. falciparum. Host cell cytotoxicity in J774 macrophages as well as the hemolysis in uninfected erythrocytes was determined $[34,35]$. The results were expressed in terms of $\mathrm{IC}_{50}$ and $\mathrm{LC}_{50}$ values. Amphotericin $\mathrm{B}$ and mefloquine were respectively

Table 4

Antiparasitic activity and cytotoxicity for the ruthenium complexes.

\begin{tabular}{|c|c|c|c|c|c|}
\hline \multirow[t]{2}{*}{ Compounds } & \multicolumn{2}{|c|}{ L. amazonensis, $\mathrm{IC}_{50} \pm \mathrm{SEM}(\mu \mathrm{M})$} & \multirow{2}{*}{$\begin{array}{l}\text { P. falciparum } \\
\mathrm{IC}_{50} \pm \operatorname{SEM}(\mu \mathrm{M})\end{array}$} & \multirow{2}{*}{$\begin{array}{l}\text { Cytotoxicity }^{(\mathrm{d})} \\
\mathrm{LC}_{50} \pm \operatorname{SEM}(\mu \mathrm{M})\end{array}$} & \multirow[t]{2}{*}{$\mathrm{SI}^{(\mathrm{e})}$} \\
\hline & Promastigotes $^{(a)}$ & In vitro infection ${ }^{(\mathrm{b})}$ & & & \\
\hline Lapachol & $12.4 \pm 0.69$ & $>10$ & $11.3 \pm 4.1$ & $>10$ & N.D. \\
\hline (1) & $>10$ & $0.07 \pm 0.002$ & $43.5 \pm 0.71$ & $0.33 \pm 0.08$ & 4.7 \\
\hline (2) & $0.18 \pm 0.04$ & $0.17 \pm 0.01$ & $0.35 \pm 0.26$ & $1.0 \pm 0.46$ & 5.9 \\
\hline (3) & $0.42 \pm 0.03$ & $>10$ & $0.53 \pm 0.28$ & $6.7 \pm 1.3$ & N.D. \\
\hline (4) & $1.6 \pm 0.44$ & N.D. & $0.19 \pm 0.17$ & $1.9 \pm 1.3$ & N.D. \\
\hline (5) & $0.14 \pm 0.04$ & 0.57 & $0.21 \pm 0.10$ & $>10$ & 17.5 \\
\hline Mefloquine & - & - & $0.04 \pm 0.01$ & - & N.D. \\
\hline Amphotericin B & $0.13 \pm 0.01$ & $0.23 \pm 0.09$ & - & $>10$ & N.D. \\
\hline Gentian Violet & - & N.D. & N.D. & $0.60 \pm 0.07$ & - \\
\hline
\end{tabular}

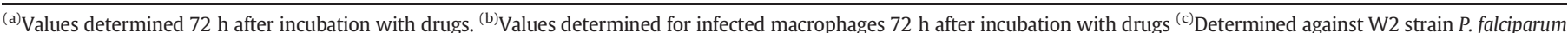

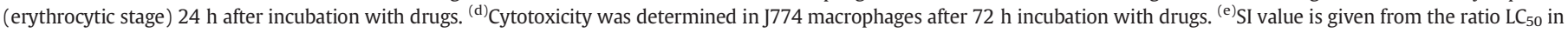

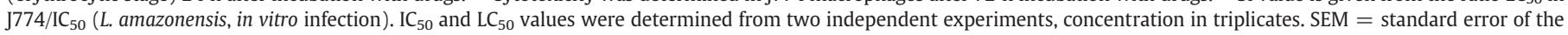
mean; N.D. $=$ not determined. $\mathrm{SI}=$ selectivity index. 


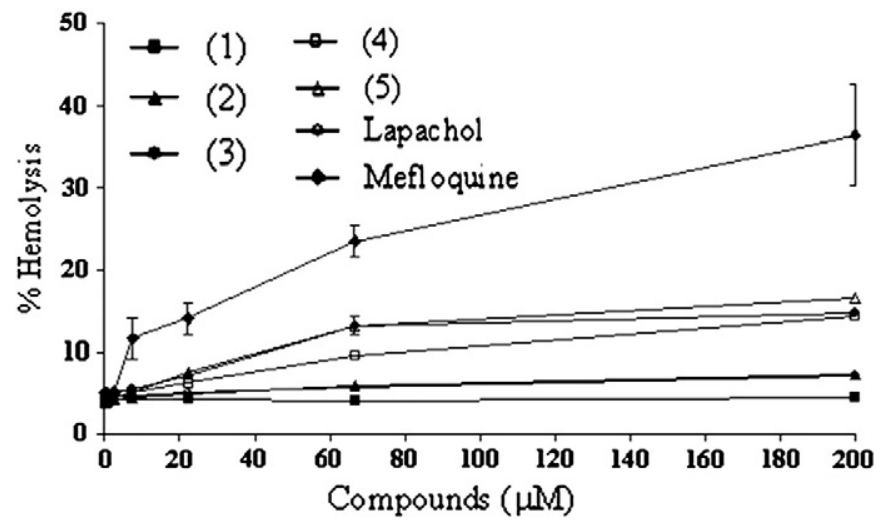

Fig. 4. Hemolytic activity of lapachol and complexes. The hemolytic activity of the compounds was assayed in fresh human erythrocytes type $\mathrm{O}^{+}$. Saponin was used as hemolytic drug at $1 \% v / v$. Released hemoglobin was monitored by measuring the absorbance at $540 \mathrm{~nm}$ in a spectrophotometer. Results shown are mean \pm SD of one experiment performed in triplicate.

used as reference drugs for Leishmania and Plasmodium tests respectively, while gentian violet was used as control in host cell cytotoxicity.

Amphotericin B, which was used as a reference drug, exhibited an $\mathrm{IC}_{50}=0.13 \pm 0.01 \mu \mathrm{M}$, while lapachol was in practice, inactive against L. amazonensis promastigotes. Complex (1) was inactive to inhibit promastigotes, while complexes (2-5) were able to inhibit their proliferation. Specifically, complexes (2) and (5) exhibited activity against promastigotes similar to the observed for amphotericin B. Regarding the inhibitory activity in $L$. amazonensis-infected macrophages, amphotericin B displayed an $\mathrm{IC}_{50}=0.23 \pm 0.09 \mu \mathrm{M}$, while lapachol was inactive. In this assay, complexes (3) and (4) were also inactive. In contrast, complexes (1), (2) and (5) were able to reduce the Leishmania infection in macrophages, with similar potency to the observed for amphotericin B.

The cytotoxicity towards host cells was also determined for all five complexes, including lapachol. Gentian violet had a $\mathrm{LC}_{50}=0.60 \pm$ 0.07 , while lapachol was non-toxic, having a $\mathrm{LC}_{50}>10 \mu \mathrm{M}$ for J774 macrophages. In comparison to lapachol, complexes (1-4) were more cytotoxic, while complex (5) was not cytotoxic. The selectivity index was calculated and shown in Table 4. Considering the antileishmania activity, complex (5) exhibited high selectivity index, while complexes (1-2) showed indexes lower than complex (5).

Next, the antimalarial activity for these complexes was evaluated. Lapachol displayed a weak activity to inhibit $P$. falciparum in comparison to mefloquine. It was observed that complex (1) showed a poor activity, while the complexes (2-5) were several times more potent than free lapachol. The most potent complexes against $P$. falciparum were (4) and (5). These complexes were fifty times more potent than free lapachol and only five times less potent than mefloquine. In addition, the effects of complexes (1-5), as well as of free lapachol, in causing hemolysis were evaluated and the percentage of hemolysis was calculated. Saponin, was used as the reference drug to cause hemolysis to the erythrocytes (Fig. 4). Lapachol did not cause hemolysis. The complexes (1-5) failed to cause not even $50 \%$ of hemolysis at $200 \mu \mathrm{M}$. This suggests that the reported anti-P. falciparum activity was not caused by the red blood cells lyses.

\section{Conclusions}

In summary, five new ruthenium (II) and (III) complexes containing lapachol as ligand were synthesized and characterized by a combination of NMR, EPR, FTIR, and X ray diffraction techniques. The evaluation of antiparasitic activities of the complexes against L. amazonensis and $P$. falciparum demonstrated that the lapachol-ruthenium complexes are more potent than the free lapachol. The $\left[\mathrm{RuCl}_{2}(\mathrm{Lap})(\mathrm{dppb})\right]$ complex is the most potent and selective antiparasitic compound among the five new ruthenium complexes studied in this work, exhibiting an activity comparable to the one of reference drugs. Specifically, lapachol-ruthenium complexes displayed potent and selective antileishmanial activity.

\section{Acknowledgments}

This study received support from CNPq, FAPESP, FAPESB and CAPES. T.S.M. holds a FAPESB scholarship. R.S.C. thanks FAPESP for a PhD fellowship (Grant number 2009/08131-1). The authors acknowledge the assistance of Diogo Rodrigo de Magalhães Moreira for helpful discussions during the preparation of the manuscript.

\section{Appendix A. Supplementary data}

Coordinates and other crystallographic data have been deposited with the CCDC, deposition codes CCDC 973562 and 973365 , for the complexes (1) and (5), respectively. Copies of this information may be obtained from The Director, CCDC, 12 Union Road, Cambridge, CB2 1EZ, UK, Fax: + 441233 336033, E-mail: deposit@ccdc.cam.ac.uk or www. ccdc.cam.ac.uk. Supplementary data to this article can be found online at http://dx.doi.org/10.1016/j.jinorgbio.2014.03.009.

\section{References}

[1] P. Baiocco, G. Colotti, S. Franceschini, A. Ilari, J. Med. Chem. 52 (2009) 2603-2612.

[2] B. Monge-Maillo, R. López-Vélez, Drugs 73 (2013) 1889-1920.

[3] S. Sundar, J. Chakravarty, Expert. Opin. Pharmacother. 14 (2013) 53-63.

[4] J.K. Baird, N. Engl. J. Med. 352 (2005) 1565-1577.

[5] H. Hussain, K. Krohn, V.U. Ahmad, G.A. Miana, I.R. Green, Arkivoc 3 (2007) 145-171.

[6] F. Epifano, S. Genovese, S. Fiorito, V. Mathieu, R. Kiss, Phytochem. Rev. 13 (2014) 37-49.

[7] J.J. Lu, J.L. Bao, G.S. Wu, W.S. Xu, M.Q. Huang, X.P. Chen, Y.T. Wang, Anticancer Agents Med. Chem. 13 (2013) 456-463.

[8] P. Guiraud, R. Steiman, G.M. Campos-Takaki, F. Seigle-Murandi, Planta Med. 60 (1994) 373-374.

[9] N.M. Lima, C.S. Correia, L.L. Leon, G.M. Machado, M.F. Madeira, A.E. Santana, M.O. Goulart, Mem. Inst. Oswaldo Cruz 99 (2004) 757-761.

[10] E. Pérez-Sacau, R.G. Díaz-Peñate, A. Estévez-Braun, A.G. Ravelo, J.M. GarcíaCastellano, L. Pardo, M. Campillo, J. Med. Chem. 50 (2007) 696-706.

[11] M.A. Souza, S. Johann, L.A. Lima, F.F. Campos, I.C. Mendes, H. Beraldo, E.M. de SouzaFagundes, P.S. Cisalpino, C.A. Rosa, T.M. Alves, N.P. de Sá, C.L. Zani, Mem. Inst. Oswaldo Cruz 108 (2013) 342-351.

[12] E.N. da Silva, C.F. de Deus, B.C. Cavalcanti, C. Pessoa, L.V. Costa-Lotufo, R.C Montenegro, M.O. de Moraes, M.C. Pinto, C.A. de Simone, V.F. Ferreira, M.O. Goulart, C.K. Andrade, A.V. Pinto, J. Med. Chem. 53 (2010) 504-508.

[13] S. Oramas-Royo, C. Torrejón, I. Cuadrado, R. Hernández-Molina, S. Hortelano, A Estévez-Braun, B. de Las Heras, Bioorg. Med. Chem. 21 (2013) 2471-2477.

[14] A.P. Neves, M.X. Pereira, E.J. Peterson, R. Kipping, M.D. Vargas, F.P. Silva Jr., J.W. Carneiro, N.P. Farrell, J. Inorg. Biochem. 119 (2013) 54-64.

[15] M.N. Rocha, P.M. Nogueira, C. Demicheli, L.G. de Oliveira, M.M. da Silva, F. Frézard M.N. Melo, R.P. Soares, Bioinorg. Chem. Appl. 2013 (2013) 1-7.

[16] L.G. Oliveira, M.M. Silva, F.C. Paula, E.C. Pereira-Maia, C.L. Donnici, C.A. Simone, F Frézard, E.N. Silva, C. Demicheli, Molecules 16 (2011) 10314-10323.

[17] G.L. Parrilha, R.P. Vieira, P.P. Campos, G.D. Silva, L.P. Duarte, S.P. Andrade, H. Beraldo, Biometals 25 (2012) 55-62.

[18] W. Kandioller, E. Balsano, S.M. Meier, U. Jungwirth, S. Göschl, A. Roller, M.A. Jakupec W. Berger, B.K. Keppler, C.G. Hartinger, Chem. Commun. 49 (2013) 3348-3350.

[19] G.-J. Lin, G.-B. Jiang, Y.-Y. Xie, H.-L. Huang, Z.-H. Liang, Y.-J. Liu, J. Biol. Inorg. Chem. 18 (2013) 873-882.

[20] Y.-Y. Xie, H.-L. Huang, J.-H. Yao, G.-J. Lin, G.-B. Jiang, Y.-J. Liu, Eur. J. Med. Chem. 63 (2013) 603-610.

[21] Enraf-Nonius,COLLECT. Nonius BV, Delft, The Netherlands, 1997-2000.

[22] Z. Otwinowski, W. Minor, Methods Enzymol. 276 (1997) 307-326.

[23] G.M.A. Sheldrick, Acta Crystallogr. A Found. Crystallogr. 64 (2008) 112-122

[24] P. Coppens, L. Leiserowitz, D. Rabinovich, Acta Crystallogr. 18 (1965) 1035-1038

[25] L.J. Farrugia, J. Appl. Crystallogr. 32 (1999) 837-838.

[26] E.R. dos Santos, M.A. Mondelli, L.V. Pozzi, R.S. Corrêa, H.S. Salistre-de-Araújo, F.R. Pavan, C.Q.F. Leite, J. Ellena, V.R.S. Malta, S.P. Machado, A.A. Batista, Polyhedron 51 (2013) 292-297.

[27] A.A. Batista, M.O. Santiago, C.L. Donicci, I.S. Moreira, P.C. Healy, S.J. Berners-Price, S.L Queiroz, Polyhedron 20 (2001) 2123-2128.

[28] L.R. Dinelli, A.A. Batista, K. Wohnrath, M.P. de Araujo, S.L. Queiroz, M.R. Bonfadini, G. Oliva, O.R. Nascimento, P.W. Cyr, K.S. MacFarlane, B.R. James, Inorg. Chem. Commun. 38 (1999) 5341-5345.

[29] A.A. Batista, K. Wohnrat, E.E. Castellano, I.S. Moreira, J. Elena, L.R. Dinelli, M.P. Araujo, J. Chem. Soc. Dalton Trans. 19 (2000) 3383-3386.

[30] Q.A. de Paula, R.W. Franco, M.B. Ribeiro, J. Ellena, E.E. Castellano, O.R. Nascimento, A. A. Batista, J. Mol. Struct. 891 (2008) 64-74 
[31] P.A.L. Ferraz, F.C. de Abreu, A.V. Pinto, V. Glezer, J. Tonholo, M.O.F. Goulart, J. Electroanal. Chem. 507 (2001) 275-286.

[32] R. Hernández-Molina, I. Kalinina, P. Esparza, M. Sokolov, J. Gonzalez-Platas, A Estévez-Braun, E. Pérez-Sacau, Polyhedron 26 (2007) 4860-4864.

[33] V.P. Rocha, F.R. Nonato, E.T. Guimarães, L.A.R. de Freitas, M.B.P. Soares, J. Med Microbiol. 62 (2013) 1001-1010.
[34] R. Dejardins, C. Canfield, J. Haynes, J. Chulay, Antimicrob. Agents Chemother. 16 (1979) 710-718

[35] C. Wang, X. Qui, B. Huang, F. He, C. Zeng, Biochem. Biophys. Res. Commun. 402 (2010) 773-777. 